\title{
The Influence Of Foreign Operations And Their Disclosure On Earnings Quality
}

Fang Hu, City University of Hong Kong, China

Sixian Yang, Colorado State University - Pueblo, USA

Don E. Giacomino, Marquette University, USA

\begin{abstract}
This paper investigates the influence of foreign operations and their financial disclosure on earnings quality in terms of accounting conservatism (timely recognizing losses). In a large (7,311 corporate years) sample of U.S. corporations, we find earnings of firms with multinational operations (MNCs) tend to be of lower quality and are reported less conservatively than those without foreign operations (domestic firms). Further, by looking at the geographic segment information disclosed by MNCs, we find that earnings conservatism gets improved if a MNC reports "clean" segment information of foreign operations; wherein operating results of MNC are broken down by geographic regions (continent or country) and reported separately. This study has implications for monitoring foreign operations and regulations that may improve earnings quality in the global economy.
\end{abstract}

Keywords: Foreign Operations, Financial Disclosure, Conservatism, Quality of Earnings

\section{INTRODUCTION}

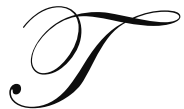

his paper investigates the influence of foreign operations and their disclosures on earnings quality in terms of accounting conservatism. We examine two related issues (1) how foreign operations influence earnings quality and (2) whether differences in foreign operations disclosure requirements improve earnings quality. As such, this investigation is motivated by increasing attention to international operations in the global economy, contradictory findings in the literature regarding foreign earnings, and a growing concern about the effectiveness of disclosure requirements of foreign operations.

These issues are of interest because of the prevalence of MNCs and the impact on earnings quality of foreign earnings on evaluations of the company's current and future profitability. As shown in subsequent descriptive analysis, only approximately 5\% of U.S. listed firms are classified as domestic (without foreign operations revenues); all other firms are classified as multinational corporations (MNCs, or firms with foreign operations revenues). Several studies examine the contribution of foreign operations to the firm value; however, those studies offer contradictory results. For example, some researchers argue that investors value foreign earnings significantly more than they do domestic earnings (Bodnar \& Weintrop, 1997; Errunza \& Senbet, 1984; Morck \& Yeung, 1991), whereas others find opposite results (Boatsman, Behn, \& Patz, 1993; Christophe \& Pfeiffer, 2002, 2000; Denis, Denis, \& Yost, 2000). These studies contribute to the debate about how foreign operations are reflected in the firm value, but that is just one aspect of the quality of foreign earnings (forecasting roles) perceived by investors. This investigation attempts to examine earnings quality of foreign operation from the aspect of its contracting roles, measured by timely reporting of economic losses (conservatism). This may restrain management's opportunistic behavior in reporting earnings and function as a means to address moral hazard problems (Watts, 2003).

By considering the practice of conservatism in earnings, foreign operations may influence earnings quality in alternative ways. On the one hand, earnings of multinational corporations (MNCs) may be more conservative or timelier in reporting losses occurred in foreign operations. Due to differences in laws, tax policies, languages, and local competition, overseas operations tend to be more difficult to control and suffer more risks and uncertainty (Christophe, 2002; Eaker, Fabozzi, \& Grant, 1996; Jensen, 1986). However, managers can meet these challenges to some extent, if they act conservatively and recognize "bad news" more readily than "good news." On the other hand, 
earnings in MNCs may be less conservative because foreign operations embody the moral hazard problems. Foreign operations, because of their potential for free cash flow, (Jensen, 1986; Pacter, 1993) often provide a desirable outlet for suboptimal investments with negative project value With more free cash flow available for spending at their discretion, managers may be motivated to introduce more bias and noise into the earnings and cause earnings to be less informative to contracting parties. In addition, the monitoring of managerial decision-making can be more difficult in a complex, globally diversified firm (Bodnar et al., 1999). Hence, moral hazard problems embodied in foreign operations and control costs result in poorer earnings quality.

With these conflicting views, this study applies the piecewise linear model (Basu, 1997) to measure earnings conservatism and uses a sample obtained from CRSP during fiscal year 1998-2006 to test the influence of foreign operations on earnings quality. The empirical results show that earnings of firms that have international operations (i.e., MNCs) generally are less conservative than those without international operations, suggesting earnings quality is poorer in firms with foreign operations and potentially the predominance of moral hazard problems.

Faced with potential moral hazard problems, which may have resulted in poorer foreign earnings quality, regulators in the U. S. in fact have set disclosure requirements on foreign operations (Berger et al 2003; Herrmann et al 2000; Lobo et al 1998)). For example, the Securities and Exchange Commission (SEC) requires firms with international operations to disclose components of their income (loss) before income tax expenses (benefit) as either domestic or foreign [Regulation 210.4-08(h), General Notes to Financial Statements-Income Tax Expense]. SFAS No. 14, issued and effective since 1976, requires companies to disclose operating information (sales, operating profit, and assets) for their foreign operations if either revenue from foreign operations exceeds 10 percent of consolidated revenue, or foreign assets exceeds 10 percent of consolidated assets. In addition, if a firm has significant foreign operations in more than one geographic area, then the firm must disclose the foreign operating information for each region separately. SFAS No. 131, issued and effective since the end of 1997, requires that disaggregated information be presented based on how management internally evaluates the operating performance of its business units. In accordance with the objectives and basic principles of SFAS No. 131, the standards allow multiple operating segments to be combined into one operating segment if the operating segments have "similar" economic and basic characteristics. While SFAS No. 131 would largely eliminate the geographic disclosure requirements previously mandated under SFAS No. 14, it requires that segment information should be reported to external users in the same manner as reported internally (Berger et al. 2002).

However, doubts arise regarding whether the disclosure of foreign operations could improve the usefulness of earnings for forecasting firm value (Ahadiat, 1993; Boatsman et al. 1993; Chrisophe et al. 2002; Behn et al. 2002). The effect of financial disclosure on the foreign earnings quality is still unclear in prior studies. By examining the specific disclosure of foreign operations in CRSP dataset, we classify the disclosure of foreign operations into "clean" and "dirty" disclosures. "Clean" disclosure means that the data reported by the MNC is broken out separately for each geographic region, continent or country, in which the firm operates and creates sales revenues. "Dirty" disclosure means that the data reported by the MNC is aggregated or mixed or not disclosed for geographic regions. We argue that earnings quality is improved (more conservative) if the disclosure of foreign operations is clean. This implies that the specific financial disclosures would mitigate the moral hazard problems reflected in foreign operations reporting and therefore improve earnings quality.

Several compelling reasons prompt this investigation. First, few studies examine the contracting roles of earnings in MNCs affected by foreign operations which embody manager's opportunistic behavior. As known, international trade and the global capital market have risen rapidly, increasing both the number of MNCs and their influences considerably. In the past decade, a steady stream of research has examined foreign earnings quality from the perspective of "value-relevance" which measures quality according to the impact on investors' valuation (e.g., Bodnar \& Weintrop, 1997; Boatsman et al., 1993; Christophe, 2002; Morck \& Yeung, 1991). Findings remained mixed. However, having realized that the manager's incentives ultimately shape earnings quality recent literature (Ball, Robin, \& Wu, 2003; Brown \& Higgins, 2001; Bushman \& Piotroski, 2006), considers conservative reporting in terms of the timeliness of recognizing economic loss in accounting income to measure earnings quality. This could reflect managers' practices in accounting for contracting efficiency and contain managers' opportunistic behavior (Ball, Kothari, \& Robin, 2000; Ball \& Shivakumar, 2006; Basu, 1997; Watts, 2003). Hence, exploring foreign earnings from this angle should contribute to a better understanding and assessment of accounting information quality of foreign operations. 
Second, how to monitor foreign operations through financial reporting is a crucial issue (Ahadiat, 1993; Boatsman et al. 1993; Chrisophe et al. 2002; Behn et al. 2002). Driven by the needs to monitor and improve the quality of foreign earnings, regulators implement requirements for disclosures of foreign operation. Prior studies have not resolved the issue of whether the disclosure requirement could mitigate the moral hazard problems and improve earnings quality of foreign operations. This study contributes to both literature and regulation by providing evidence on effectiveness of financial disclosure regulations which exert influence on foreign earnings reporting. In the following sections of this article, we develop hypotheses, describe the sample and research design, discuss the results and offer our conclusions.

\section{Hypothesis Development}

Foreign operations encompass countries from around the world, with drastically different economic conditions, political structures, competitive forces, growth opportunities, and governmental regulations. Given existing arguments about foreign operations, several perspectives relate to their influences on the earnings quality of MNCs if manager's reporting incentives are considered.

On the one hand, earnings may be of higher quality (i.e., more conservative) under the effect of foreign operations because higher earnings quality is efficient for contracting parties (investors, creditors, auditors, and other users) and helps mitigate shareholder litigation (Basu, 1997; Watts, 2003), with higher uncertainty or risk in foreign operations. Foreign operations may represent underexploited, high-growth investment opportunities that can result in greater returns and risks (Bodnar \& Weintrop, 1997; Errunza \& Senbet, 1984; Morck \& Yeung, 1991). Overseas operations also are more difficult to control and suffer more risks or uncertainty because of differences in laws, tax policies, languages, and competition (Christophe, 2002; Eaker et al., 1996; Jensen, 1986). Therefore, if managers act conservatively and practice accounting conservatism, they can somewhat compensate for the negative impact of risk and uncertainty in foreign operations. Conservatism also offsets the managerial biases in financial reporting that get introduced by uncertainty in foreign operations and increases the earnings quality used by various contracting parties (Watts, 2003).

On the other hand, earnings may be of lower quality (i.e., less conservative) under the effect of foreign operations because of the moral hazard problems embodied in foreign operations. Foreign operations can offer desirable outlets for suboptimal investments, motivated by free cash flow availability (Jensen, 1986; Pacter, 1993). Therefore, foreign operations may represent suboptimal investments with a negative net present value (NPV), undertaken primarily for the benefit of management (Christophe, 2002). Untimely (late) loss recognition - deferring recognition until the reduced cash flows underlying the negative NPV are realized - is more likely to pass the negative earnings consequences on to subsequent generations of managers. Untimely loss recognition also provides managers with an accounting-based incentive to continue operating negative cash-flow investments and strategies, in order to avoid booking losses on sales or abandonment of assets. The moral hazard problems might result in less conservative earnings or poorer contracting roles of earnings.

Prior studies suggest that the moral hazard hypothesis may play a dominant role in the MNCs of U. S. corporations. Brown (2001) provided empirical evidence that U.S. managers are relatively more likely to manage earnings surprises to create small positive profit surprises, as a result of information asymmetry caused by widely dispersed ownership. In addition, monitoring of managerial decision-making can be more difficult in a complex, globally-diversified firm (Bodnar et al., 1999). Hence, it is hypothesized as:

H1(a): Earnings in MNCs with foreign operations are of lower quality or less conservative than those in firms without foreign operations.

H1(b): For the earnings in MNCs, the foreign component is of lower quality or less conservative than the domestic component.

Attempting to strengthen monitoring to potential moral hazard problems occurring in foreign operations, regulators implement the disclosure requirements for reporting foreign operations. For example, the Financial Accounting Standards Board (FASB) has issued and implemented SFAS No. 14 requirement since 1976; SFAS No. 131 has been issued and implemented since the end of 1997; SEC implements Regulation 210.4-08(h); etc. 
Our second research question examines whether disclosure requirement improves earnings quality because the effectiveness of segment disclosure of foreign operations is of concern and it is controversial in prior literature regarding whether it facilitates the increased firm value or improved monitoring (Ahadiat, 1993; Boatsman et al. 1993; Behn et al. 2002; Chrisophe et al. 2002). Some argue that specific disclosure may increase transparency of foreign operation by enabling investors to assess the nature of all segment information and monitor managers' discretion (Piotroski, 1999, 2002). Increased transparency of information enforces monitoring of external users and mitigates manager's discretion so that the earnings are reported more conservatively to reduce litigation risks. Others argue financial disclosure, which also contains managers' discretion, may not facilitate improved monitoring, and might even result in inferior information content in certain contexts. For example, where firms have declining liquidity, competitive harm created by disclosure is smaller (Botosan, et al. 2000; Cooke et al 1990; Leuz, 1999).

From these arguments, surfaces an empirical question whether the financial disclosure is effective in increasing earnings quality. We conjecture that mandating the disclosure requirement might result in superior information content because the regulators insist on increasing disclosure requirements and encourage firms to disclose as many details as they can in their reports. Therefore, we examine it as follows:

H2: Earnings quality in MNCs increases or is more conservative with specific disclosure of foreign operations.

\section{Sample and Research Design}

There are a number of different that could be employed to measure the firm's foreign operations. We have chosen to use foreign sales as our metric because we feel it is least susceptible to reporting distortions which might arise when a firm engages in transfer pricing for its foreign operations. We also perform our tests using alternative metrics to measure the foreign operations. For example, we use foreign assets to measure foreign operations. We also use foreign operating income to measure foreign operations and find that the results are insignificant. Perhaps, this is because companies are allowed wide discretion in how they report this figure which is exposed to more reporting distortions.

Table 1: Descriptive Statistics for Sample of Firms 1998 - 2006

\begin{tabular}{|c|c|c|c|}
\hline \multicolumn{4}{|c|}{$\begin{array}{l}\text { Panel A: Descriptive Statistics for the Sample of Firms Studied (Including Both Domestic Firms and Multinational } \\
\text { Corporations (MNCs) }\end{array}$} \\
\hline & Domestic Firms (Mean) & $\begin{array}{l}\text { MNCs } \\
\text { (Mean) }\end{array}$ & $\begin{array}{l}\text { Difference } \\
\text { (t-value) }\end{array}$ \\
\hline Total Assets (data6 - MM\$) & 2776.0 & 4376.9 & $\begin{array}{l}-1600.9 \\
(-1.90 *)\end{array}$ \\
\hline Total Sales (data12 - MM\$) & 1498.1 & 3440.4 & $\begin{array}{l}-1942.3 \\
(-5.51 * * *) \\
\end{array}$ \\
\hline EPS (data58) & 0.25 & 0.76 & $\begin{array}{c}-0.51 \\
(-4.86 * * *)\end{array}$ \\
\hline Net Income (data $172-\mathrm{MM} \$$ ) & 373.9 & 224.6 & $\begin{array}{c}149.3 \\
(-1.35) \\
\end{array}$ \\
\hline Return (RET) & 0.22 & 0.15 & $\begin{array}{c}0.07 \\
(1.69 *)\end{array}$ \\
\hline Abnormal Return (ABRET) & 0.02 & 0.00 & $\begin{array}{c}0.02 \\
(0.51) \\
\end{array}$ \\
\hline Bad News $($ RET $<0)$ & 0.42 & 0.47 & $\begin{array}{c}-0.05 \\
(-2.00 * *) \\
\end{array}$ \\
\hline Obs. \# & 338 & 7311 & \\
\hline \multicolumn{4}{|c|}{ Panel B: Descriptive statistics for the sample of 7,311 MNCs } \\
\hline & $\begin{array}{l}\text { Domestic Operations } \\
\text { (Mean) }\end{array}$ & $\begin{array}{c}\begin{array}{c}\text { Foreign Operations } \\
(\text { Mean })\end{array} \\
\end{array}$ & $\begin{array}{c}\text { Total } \\
(\text { Mean })\end{array}$ \\
\hline Net Income (MM\$) & 90.55 & 101.27 & 224.6 \\
\hline Sales (MM\$) & 3944.00 & 1716.30 & 3440.4 \\
\hline EPS & 0.39 & 0.40 & 0.76 \\
\hline Frequency of loss $(\mathrm{NI}<0)$ & 0.34 & 0.25 & 0.78 \\
\hline Obs. \# & 7311 & 7311 & 7311 \\
\hline
\end{tabular}


The accounting and stock return data for this study were extracted from annual CRSP files from 1998 to 2006. We use the CRSP/COMPUSTAT merged database, for which the final data cut is July 2007 (fiscal year 2006). SFAS No. 131, the newest disclosure requirement on the foreign operations, was issued by FASB in June 1997 and has been implemented since December of 2007. Hence, we choose the period studied from 1998 to 2006 (fiscal year) in order to exclude the effect of the issuance event. The segment data (e.g., foreign sales data, segment region) were collected from the CRSP segment database.

The initial sample was selected after deleting the missing values, top and bottom $1 \%$ of outliers, and financial/utility institutions (standard industrial classification codes 4999-6999). We also exclude the non-U.S. incorporated firms so that the sample includes only U.S. incorporated firms. The final sample therefore consists of 7649 firm years, including 7311 firm years for MNCs and 338 firm years for U.S. domestic firms.

Table 1 (panel A) provides descriptive statistics and includes data for domestic firms without foreign operations and for firms with foreign operations (MNCs). Firms with international or foreign operations (MNCs) seem to hold larger-scale operations than the domestic firms, whether comparing their total assets, sales or profitability. Cumulative CRSP monthly return in the fiscal year $t$ is calculated for each firm year, and then the returns of domestic firms and MNCs are compared. Market performance of domestic firms is a bit better than that of MNCs (difference is 0.07 and t-value 1.69). In addition, MNCs have more "Bad News", and lower return, comparing to domestic firms (difference is - 0.05 and t-value -2.00).

Table 1 (panel B) also provides data for only those firms with international or foreign operations (MNCs), describing the distribution of their decomposed foreign and domestic operations. On average, these firms tend to depend more on domestic sales than on foreign sales, whereas the profitability of foreign operations is higher than profitability of domestic operations. According to the definitions provided by Callen et al (2004), the component of earnings from foreign operations is computed as:

Foreign earnings $=$ Pretax foreign income $($ DATA 273 $)-$ Foreign income taxes

$($ Foreign income taxes $=$ Taxes payable $($ DATA64 $)+$ Foreign deferred taxes $($ DATA 270 $)$.

The component of earnings from domestic operations is then computed as:

Domestic earnings $=$ Pretax domestic income $($ DATA 272) - Domestic income taxes

$($ Domestic income taxes $=$ Total income taxes $($ DATA16 $)-$ Foreign income taxes $)$.

Foreign earnings average \$101.27 MM and the domestic earnings average \$90.55 MM. A loss (negative earnings) is more likely to occur in domestic operations than in foreign operations.

Table 2 presents the number of MNCs that have various disclosures of foreign operations. By manually identifying the geographic regions reported by U. S. MNCs in their segment reports (CRSP dataset), we classify those disclosures of foreign operations into four levels. If the MNC does not disclose the geographic regions, it is classified as "No Disclosure". For example, if a firm reports operating results as "Not reported", "Foreign", "International", or "All others", then it is placed to the level of "No Disclosure". If the MNC reports the geographic regions (continental, country or city level) combined, it is classified as "Aggregated". For example, if a firm reported results for "Europe" and "Asia" combined, the company is classified as "Aggregated". If the data reported by the MNC is broken out separately for each continent, then it is classified as "Continental", e.g. a firm reported results for "Europe" and "Asia" separately. If the data reported by the MNC is broken out separately for each country, then it is classified as "Country" (e.g. a firm reports results for "Japan" and "China" separately). Since one of the purposes of this research is to examine whether the disclosure of foreign operations improves earnings quality, we define a variable "Clean" to identify MNCs reported clean information for each geographic region which is classified as either "Continental" or "Country" above. As presented in Table 2, more than 50 percent of MNCs report clean information, 16 percent of MNCs do not disclose the specific geographic regions and only three percent of MNCs disclosed aggregated results. 
Table 2: Number of Firms and Disclosures of Foreign Operations of MNCs Sample 1998-2006

\begin{tabular}{|c|c|c|c|c|c|}
\hline & & \multicolumn{4}{|c|}{ Disclosure of foreign operations } \\
\hline year & MNCs & Not disclosed & Aggregated & Continental & Country \\
\hline 1998 & 902 & 93 & 132 & 347 & 330 \\
\hline 1999 & 765 & 118 & 26 & 232 & 389 \\
\hline 2000 & 783 & 128 & 14 & 222 & 419 \\
\hline 2001 & 757 & 117 & 16 & 216 & 408 \\
\hline 2002 & 750 & 121 & 9 & 206 & 414 \\
\hline 2003 & 788 & 130 & 10 & 210 & 438 \\
\hline 2004 & 864 & 137 & 11 & 234 & 482 \\
\hline 2005 & 891 & 150 & 9 & 259 & 473 \\
\hline 2006 & 811 & 153 & 11 & 216 & 431 \\
\hline Total & 7311 & 1147 & 238 & 2142 & 3784 \\
\hline
\end{tabular}

Table 3 presents descriptive statistics for the MNCs at four levels of disclosure. The MNC's that disclose clean information have more total sales, foreign sales, assets and profits. According to SFAS No. 14, companies should disclose operating information (sales, operating profit, and assets) for their foreign operation if either revenue from foreign operations exceeds 10 percent of consolidated revenue, or foreign assets exceeds 10 percent of consolidated assets. For firms identified as "Not Disclosed" in Table 3, foreign sales occupy 70 percent of total sales on average, far exceeding the 10 percent criterion.

Table 3: Descriptive Statistics for the MNCs by Disclosure Level

\begin{tabular}{|l|c|c|c|c|}
\hline & \multicolumn{4}{|c|}{ Disclosure of foreign operations } \\
\hline & Not disclosed & Aggregated & Continental & Country \\
\hline Total Sales (data 12-MM\$) & 3283.13 & 2651.79 & 3598.07 & 3448.51 \\
\hline Total Assets (data 6-MM\$) & 4424.10 & 2781.51 & 4592.30 & 4340.98 \\
\hline Net Income (data 172-MM\$) & 127.35 & 142.74 & 196.03 & 215.79 \\
\hline EPS (data 58) & 0.72 & 1.10 & 0.75 & 0.75 \\
\hline Domestic Sales & 5232.38 & 3744.83 & 5281.41 & 6187.39 \\
\hline Foreign Sales & 2291.42 & 1594.68 & 3536.41 & 3300.68 \\
\hline Domestic Income & 72.53 & 95.00 & 81.09 & 101.09 \\
\hline Foreign Income & 61.36 & 31.63 & 118.64 & 107.93 \\
\hline Return (RET) & 0.14 & 0.03 & 0.14 & 0.17 \\
\hline Bad (RET<0) & 0.45 & 0.55 & 0.49 & 0.46 \\
\hline No. of Firms & 1147 & 238 & 2142 & 3784 \\
\hline
\end{tabular}

We use a piecewise linear model (Basu, 1997) to examine conservatism under the influence of foreign operations. Even though market returns constitute a potentially noisy measure of economic losses that trigger accounting accruals, this proxy has been the most popular for testing conservatism thus far (e.g., Ball \& Shivakumar, 2006; Basu, 1997). The model follows:

$$
\begin{aligned}
& \frac{E_{P S}}{P_{i t-1}}=\alpha+\beta_{1} * R E T_{i t}+\beta_{2} * B A D_{i t}+\beta_{3} * R E T_{i t} * B A D_{i t}+\beta_{4} * \text { FOREIGN }_{i t} \\
& +\beta_{5} * \operatorname{RET}_{i t} * B A D_{i t} * \text { FOREIGN } \\
& i t
\end{aligned}
$$

$R E T_{i t}$ is annual stock return, defined as cumulative CRSP monthly return in fiscal year $\mathrm{t}$

$B A D_{i t}$ is a proxy for bad news, which is equal to 1 if $R E T_{i t}<0,0$ otherwise

$R E T_{i t} * B A D_{i t}$ is the interaction item. Its coefficient $\left(\beta_{3}\right)$ implies the differential recognition of loss, which indicates the degree of conditional conservatism.

Foreign $_{i t}$ is a dummy variable, equal to 1 if a firm is a multinational corporation (MNC) with foreign or international operations; otherwise, 0 .

$R E T_{i t} * B A D_{i t} *$ Foreign $_{i t}$ is the interaction item. Its coefficient $\left(\beta_{5}\right)$ implies the earnings quality (conservatism) interacted with the foreign operations. 
The same model as above is used to examine conservatism under the influence of disclosure of foreign operations as follows.

$$
\begin{aligned}
& \frac{E P S_{i t}}{P_{i t-1}}=\alpha+\beta_{1} * R E T_{i t}+\beta_{2} * B A D_{i t}+\beta_{3} * \operatorname{RET}_{i t} * B A D_{i t}+\beta_{4} * C L E A N_{i t} \\
& +\beta_{5} * R E T_{i t} * B A D_{i t} * C L E A N_{i t}+\varepsilon_{i t}
\end{aligned}
$$

$R E T_{i t}, B A D_{i t}$ and $R E T_{i t} * B A D_{i t}$ are defined as above.

$C L E A N_{i t}$ is a dummy variable, equal to 1 if a MNC discloses clean information or reports each geographic region separately in which the firm operates; otherwise, 0 .

$R_{E T} * B A D_{i t} * C L E A N_{i t}$ is the interaction item. Its coefficient ( $\left.\beta_{5}\right)$ implies the earnings quality (conservatism) interacted with the specific disclosure of foreign operations.

\section{RESULTS}

For the sample of both domestic and international firms, our tests evaluate overall earnings quality under the influence of international or foreign operations. First, we performed tests with the original Basu's model. Results in the first column of Table 4 show that overall earnings possess the attribute of conservatism ( $\beta_{3}$ is 0.26 and $p$ $<.0001)$. Then, we test the model with interaction by foreign operations. Results in the second column of Table 4 support the moral hazard hypothesis in foreign operations, where foreign operations lowered the conservatism of earnings or earnings quality. Specifically, $\beta_{3}$ is significantly positive $(0.41, p<.0001)$, which means that domestic firms' timeliness of incorporating losses vs. gains is more asymmetrical than that of MNCs. The significantly negative $\beta_{5}$ suggests a negative incremental effect of foreign operations on conservatism $(-0.15, p=0.001)$, such that the speed with which firms with foreign operations recognize the loss is $0.26\left(\beta_{3}+\beta_{5}: 0.41-0.15\right)$, slower or less conservative than firms without foreign operations (0.41). Therefore, these findings support H1(a), which states "Earnings in MNCs with foreign operations are of lower quality or less conservative than those in firms without foreign operations."

Table 4: Tests of Influence of Foreign Operations on Conservatism of Earnings Basu's (1997) Domestic and Multinational Corporations (MNCs)

$$
\begin{aligned}
& \frac{E P S_{i t}}{P_{i t-1}}=\alpha+\beta_{1} * R E T_{i t}+\beta_{2} * B A D_{i t}+\beta_{3} * R E T_{i t} * B A D_{i t}+\beta_{4} * \text { FOREIGN }_{i t} \\
& +\beta_{5} * R E T_{i t} * B A D_{i t} * F O R E I G N_{i t}+\varepsilon_{i t}
\end{aligned}
$$

\begin{tabular}{|l|c|c|}
\hline & Dep. Var. (EPS) & Dep. Var. (EPS) \\
\hline INTERCEPT & 0.03 & 0.01 \\
& $(<.0001 * * *)$ & $-0.367)$ \\
\hline RET & -0.03 & $(<.0001 * * *)$ \\
\hline BAD & $(<.0001 * * *)$ & 0.01 \\
& 0.01 & $(0.037 * *)$ \\
\hline RET*BAD & $(0.040 * *)$ & 0.41 \\
& 0.26 & $(<.0001 * * *)$ \\
\hline FOREIGN & $(<.0001 * * *)$ & 0.02 \\
& & $(0.081 *)$ \\
\hline RET*BAD*FOREIGN & & -0.15 \\
& & $(0.001 * * *)$ \\
\hline Adj R-Sq & 0.07 & 0.08 \\
\hline
\end{tabular}

Note: the number in parenthesis is $\mathrm{p}$ value. $* * * \mathrm{p}<1 \%, * * \mathrm{p}<5 \%, *<10 \%$.

$\mathrm{EPS}=$ earnings per share scaled by the price of previous year;

$\mathrm{RET}=$ the accumulated monthly return in a fiscal year;

$\mathrm{BAD}=1$ if $\mathrm{RET}<0$; otherwise 0 ;

FOREIGN $=1$ if foreign sale (FSALE) is not 0 ; otherwise 0 . 
Table 5 further decomposes the total earnings of firms with foreign operations (MNCs) into foreign and domestic earnings to compare the quality of two components. Foreign earnings-per-share is less conservative $(0.05$, $p<.0001)$ than domestic earnings-per-share $(0.20, p<.0001)$, although both recognize losses in a timely fashion. In addition, the adjusted R-square of foreign earnings model (0.03) is lower than that of domestic model (0.06). Thus, both the magnitude of the coefficient and the explanatory power of the regression model support the view that foreign earnings are of lower quality than domestic earnings. Taken together, the results in Tables 4 and 5 indicate that earnings with foreign operations get reported less conservatively and are of lower quality.

Table 5: Tests Comparing Conservatism of Two Components (7,311 MNCs) Decomposed Foreign and Domestic Earnings from Basu's (1997) model

$$
\begin{aligned}
& \frac{E P S D_{i t}}{P_{i t-1}}=\alpha+\beta_{1} * R E T_{i t}+\beta_{2} * B A D_{i t}+\beta_{3} * R E T_{i t} * B A D_{i t}+\varepsilon_{i t} \\
& \frac{E P S F_{i t}}{P_{i t-1}}=\alpha+\beta_{1} * R E T_{i t}+\beta_{2} * B A D_{i t}+\beta_{3} * R E T_{i t} * B A D_{i t}+\varepsilon_{i t}
\end{aligned}
$$

\begin{tabular}{|l|c|c|}
\hline & Dep. Var. (EPSD) & Dep. Var. (EPSF) \\
\hline INTERCEPT & 0.01 & 0.02 \\
& $(<.0001 * * *)$ & $(<.0001 * * *)$ \\
\hline RET & -0.03 & -0.001 \\
& $(<.0001 * * *)$ & $(0.209)$ \\
\hline BAD & 0.01 & 0.00 \\
& $(0.023 * *)$ & $(0.674)$ \\
\hline RET*BAD & $\mathbf{0 . 2 0}$ & $\mathbf{0 . 0 5}$ \\
& $(<.0001 * * *)$ & $(<.0001 * *)$ \\
\hline Adj R-Sq & 0.06 & 0.03 \\
\hline
\end{tabular}

Note: the number in parenthesis is $\mathrm{p}$ value. $* * * \mathrm{p}<1 \%, * * \mathrm{p}<5 \%, *<10 \%$.

EPSD $=$ Domestic earnings divided by shares used for EPS calculation, scaled by the price of previous year;

$\mathrm{EPSF}=$ Foreign earnings divided by shares used for EPS calculation, scaled by the price of previous year;

$\mathrm{RET}=$ the accumulated monthly return in the fiscal year;

$\mathrm{BAD}=1$ if $\mathrm{RET}<0$; otherwise 0 .

The next test considers how earnings quality might be influenced by the disclosure of foreign operations. In Table 6, firms with no foreign operations are deleted and the sample of MNCs is studied. The results in Table 6 suggest that "clean" disclosure of foreign operations has a significant and positive impact on the earnings quality, because the incremental effect of "clean" disclosure of foreign operations on conservatism is positive. Specially, $\beta_{3}$ is significantly positive $(0.22, p<.0001)$, which means that earnings in firms which disclose clean information incorporate the losses more timely than those disclose non-clean information. The significantly positive $\beta_{5}$ suggests a positive incremental effect of "clean" disclosure on conservatism $(0.04, p=0.084)$, such that the speed with which firms that report clean information of foreign operations recognize the loss is $0.26\left(\beta_{3}+\beta_{5}: 0.22\right.$ $+0.04)$, faster or more conservative than firms that disclose non-clean foreign operations $(0.22)$. 
Table 6: Tests of Influence of Foreign Operations Disclosure on Earnings Quality Basu's Model (1997)

$$
\begin{aligned}
& \frac{E^{2} S_{i t}}{P_{i t-1}}=\alpha+\beta_{1} * R E T_{i t}+\beta_{2} * B A D_{i t}+\beta_{3} * \operatorname{RET}_{i t} * B A D_{i t}+\beta_{4} * C L E A N_{i t} \\
& +\beta_{5} * R E T_{i t} * B A D_{i t} * C L E A N_{i t}+\varepsilon_{i t}
\end{aligned}
$$

\begin{tabular}{|l|c|}
\hline & Dep. Var. (EPS) \\
\hline INTERCEPT & 0.03 \\
& $\left(<.0001^{* * *}\right)$ \\
\hline RET & -0.03 \\
& $\left(<.0001^{* * *}\right)$ \\
\hline BAD & 0.01 \\
& $\left(0.034^{* *}\right)$ \\
\hline RET*BAD & 0.22 \\
& $\left(<.0001^{* * *)}\right.$ \\
\hline CLEAN & 0.005 \\
& $(0.416)$ \\
\hline RET*BAD*CLEAN & 0.04 \\
& $(0.084 *)$ \\
\hline Adj R-Sq & 0.07 \\
\hline
\end{tabular}

Note: the number in parenthesis is $\mathrm{p}$ value. $* * * \mathrm{p}<1 \%, * * \mathrm{p}<5 \%, *<10 \%$.

EPS $=$ the total earnings in the MNCs, scaled by the price of previous year;

$\mathrm{RET}=$ the accumulated monthly return in the fiscal year;

$\mathrm{BAD}=1$ if RET <0; otherwise 0 ;

CLEAN = 1 if the data reported by the MNC is broken out separately for each geographic region, continent or country, in which the firm operates and creates sales revenues; otherwise, 0 if the data reported by the MNC is aggregated or mixed or not disclosed for geographic regions.

We perform some robustness checks using an adjusted Basu's (1997) model. Some arguments arise in prior studies regarding Basu's model to test the conservatism of earnings (Ball et al. 2006; Givoly et al. 2004). Ball et al. (2006) adjust Basu's model by investigating the role of accrual accounting in the asymmetrically timely recognition of unrealized gains and losses. We perform our tests according to their adjustment, using accruals as the dependent variable, which is measured using cash flow (CF) model, Dechow-Dichev (DD) model or Jones model. The results consistently support the hypothesis. Second, we perform the tests in which "bad news" is measured by negative abnormal returns (firm returns minus market returns, < 0), or non-market proxies (cash flow from operations < 0). The results still support the hypothesis.

\section{CONCLUSIONS}

Previous studies in this field investigated how investors perceive the magnitude of the foreign earnings of MNCs in determining the firm value. Those studies provide mixed results. By considering the contracting role of earnings in multinational corporations (MNCs), this study sheds new light on foreign earnings.. At the beginning of this article, we argue that earnings quality is improved (more conservative) if the disclosure of foreign operations is clean. Our findings support this argument. We find that "clean" disclosure (data reported by the MNC is broken out separately for each geographic region, continent or country, in which the firm operates and creates sales revenues) does improve earnings quality. In turn, these results call for greater monitoring mechanisms to watch for managers' manipulations of foreign operations and increased vigilance by regulators in their efforts to uphold international disclosures standards. This study also finds that foreign operations have a negative influence on earnings quality in terms of conservatism. This result may reflect managers' opportunistic behavior and affect the contracting role of earnings

\section{AUTHOR INFORMATION}

Dr. Fang Hu is a visiting fellow in the Department of Accountancy at City University of Hong Kong. She received her doctoral degree from City University of Hong Kong. She is a member of the American Accounting Association, the American Finance Association, and the Canadian Academic Accounting Association. Dr. Hu has written several 
working papers on control mechanisms, corporate governance and management accounting. She has made several paper presentations and served as a discussant at international and national conferences.

Ms. Sixian Yang is Research Analyst at Colorado State University - Pueblo. She received her Master of Philosophy in Accounting from City University of Hong Kong and her MBA from Marquette University. As member of the American Accounting Association, she has been active in presenting research work in conferences and writing papers in the field of accounting research and educational research. Her current research studies are focused on corporate governance, earnings quality, and accounting issues in emerging markets.

Dr. Don E. Giacomino, CPA, is Professor and the Donald and Beverly Flynn Chair Holder in the Department of Accounting at Marquette University. He received his doctoral degree from the University of Kentucky. Dr. Giacomino has authored over 50 refereed articles in academic and professional journals, including The Journal of Accountancy, the Journal of Applied Business Research, Advances in Accounting, the CPA Journal, Management Accounting, Review of Business Information Systems, Issues in Accounting, Journal of Managerial Issues, the Journal of Business and Economic Research and College Teaching and Learning.

\section{REFERENCES}

1. Ahadiat, Nasrollah, 1993. Geographic segment disclosure and the predictive ability of the earnings data. Journal of International Business Studies 24 (2), 357-371.

2. Bodnar, G., Weintrop, J. 1997. The valuation of foreign income of U. S. multinational firms: A growth opportunities perspective. Journal of Accounting and Economics 24 (1), 69-98.

3. Ball, R., Kothari, S. P., Robin, A., 2000. The effect of international institutional factors on properties of accounting earnings. Journal of Accounting \& Economics 29, 1-51.

4. Ball, R., Robin, A., Wu, J. S., 2003. Incentives versus standards: Properties of accounting income in four East Asian countries and implications for acceptance of IAS. Journal of Accounting \& Economics 36, 235-270.

5. Ball, Ray, Shivakumar, Lakshmanan. 2006. The role of accruals in asymmetrically timely gain and loss recognition. Working paper.

6. Basu, S., 1997. The conservatism principle and asymmetric timeliness of earnings. Journal of Accounting \& Economics 24, 3-37.

7. Behn, B. K., Nichols, N. B., Street, D. L., 2002. The predictive ability of geographic segment disclosures by U.S. companies: SFAS No. 131 vs. SFAS No. 14. Journal of International Accounting Research 1, 31-44.

8. Berger, Philip G., Rebecca Hann, 2003. The impact of SFAS No. 131 on information and monitoring. Journal of Accounting Research 41 (2), 162-223

9. Boatsman, J, Behn, B., Patz, D. 1993. A test of the use of geographical segment disclosures. Journal of Accounting Research 31, suppl. 46-64.

10. Bodnar, G. M., Weintrop, J., 1997. The valuation of the foreign income of US multinational firms: a growth opportunities perspective. Journal of Accounting and Economics 24, 67-97.

11. Botosan, C., M. Harris, 2000. Motivations for a change in disclosure frequency and its consequences: an examination of voluntary quarterly segment disclosures. Journal of Accounting Research 38, 329-353.

12. Brown, Lawrence D., Higgins, Huong Ngo, 2001. Managing earnings surprises in the US versus 12 other countries. Journal of Accounting and Public Policy 20, 373-398.

13. Bushman, Robert M., Piotroski, Joseph D., 2006. Financial reporting incentives for conservative accounting: the influence of legal and political institutions. Journal of Accounting and Economics 42, 107-148.

14. Callen, Jeffrey L., Hope, O.-K., \& Segal, D. 2004. Domestic and foreign earnings, stock return variability, and the impact of investor sophistication. Journal of Accounting Research 43 (3), 377-412.

15. Christophe, Stephen E. 2002. The value of U.S. MNC earnings changes from foreign and domestic operations. Journal of Business 75, 67-93.

16. Christophe, S. E., R. J. Pfeiffer, Jr., 2002. The valuation of MNC international operations during the 1990s. Review of Quantitative Finance and Accounting 18, 119-138.

17. Cooke, Terence E., Wallace, R. S. Olusegun, 1990. Financial disclosure regulation and its environment: A review and further analysis. Journal of Accounting and Public Policy 9, 79-110. 
18. Denis, D., Denis, D., Yost, K. 2000. Global diversification, industrial diversification, and firm value. Working paper. West Lafayette, Ind.: Purdue University.

19. Eaker, M.; Fabozzi, F., Grant, D. 1996. International Corporate Finance. Orlando, FL.: Dryden.

20. Errunza, V. R., Senbet, L. W. 1984. International corporate diversification, market valuation, and size-adjusted evidence. Journal of Finance 39, 727- 745.

21. Givoly, D., Hayn, C., Natarajan, A., 2004. Measuring reporting conservatism. Working paper, Pennsylvania State University.

22. Herrmann, D., Thomas, W., 2000. An analysis of segment disclosures under SFAS No. 131 and SFAS No. 14. Accounting Horizons 14, 287 - 302.

23. Jensen, M. 1986. Agency costs of free cash flow, corporate finance and takeovers. American Economic Review 76 (May), 323-29.

24. Leuz, C., 1999. Proprietary and non-proprietary disclosures: voluntary cash flow statements and business segment reports in Germany. Working paper, University of Pennsylvania.

25. Lobo, Gerald J., Kwon, Sung S., Ndubizu, Gordian A., 1998. The impact of SFAS No. 14 segment information on price variability and earnings forecast accuracy. Journal of Business Finance and Accounting 25 (7\&8), 969-985.

26. Morck, R., Yeung, B. 1991. Why investors value multi-nationality. Journal of Business 64 (April), $165-87$.

27. Pacter, P., 1993. Reporting disaggregated information. FASB, Norwalk.

28. Piotroski, J., 1999. The impact of newly reported segment information on market expectations and stock returns. Working paper, University of Chicago.

29. Piotroski, J., 2002. Segment reporting fineness and the precisions of investor beliefs. Working paper, University of Chicago.

30. Watts, R. L., 2003. Conservatism in accounting part I: Explanations and implications. Accounting Horizons $17,207-221$. 
NOTES 